2016

\title{
Virtue Pedagogy and International Law Teaching
}

Hengameh Saberi

Osgoode Hall Law School of York University, hsaberi@osgoode.yorku.ca

Follow this and additional works at: http:// digitalcommons.osgoode.yorku.ca/olsrps

\section{Recommended Citation}

Saberi, Hengameh, "Virtue Pedagogy and International Law Teaching" (2016). Osgoode Legal Studies Research Paper Series. 123.

http://digitalcommons.osgoode.yorku.ca/olsrps/123

This Article is brought to you for free and open access by the Research Papers, Working Papers, Conference Papers at Osgoode Digital Commons. It has been accepted for inclusion in Osgoode Legal Studies Research Paper Series by an authorized administrator of Osgoode Digital Commons. 
"You may know a truth, but if it’s at all complicated, you have to be an artist not to utter it as a lie."

-Iris Murdoch, An Accidental Man

\section{Introduction}

International law may be unable to boast primacy in the value of attention it receives as a pedagogical endeavor, but it can certainly depend on the exceptional gravity of that attention. ${ }^{1}$ In a colorful recounting, international law teaching competes with the worst aspects of sex and the weather in that many "think they are expert[s]; they complain about problems, but do nothing to improve the situation." 2 This is not exactly true, as what unites diagnostic accounts of international law teaching is not the absence of reform proposals. Rather, it is an enduring preoccupation with the institutional, if not necessarily ontological, identity of international law in legal education and its assignment to the periphery of academic visibility.

Corresponding to the resilience of this concern is a literature that has survived the seasonal winds of scholarship fashion since at least the 1950s. ${ }^{3}$ Across diverse academic locales, ${ }^{4}$ reflecting on particular historical phases, ${ }^{5}$ and differing at times in thematic emphasis, ${ }^{6}$ seasoned and occasional teachers of international law have consistently called for new ways to present the field in an ever more integrated market of practice. If a perception of international

\footnotetext{
${ }^{1}$ I use 'international law' to avoid the anachronism of 'public international law' and also to leave room for application of virtue theory to international legal pedagogy in general, but my topical discussion in this essay will centre around 'public international law' in response to the volume of attention it has received across generations of international law teachers.

2 John Gamble, Teaching or Get off the Lectern: Impediments to International Law Teaching, 13 ILSA J. Int'l \& Comp. L. 379, 379 (2007).

${ }^{3}$ For a list of sources with an emphasis on Australian and Canadian works see, Gerry Simpson, On the Magic Mountain: Teaching Public International Law, 10(1) Eur. J. Int'l L. 70, 70 (1999 FN 2.

${ }^{4}$ See e.g., Ivan Shearer, The Teaching of International Law in Australian Law Schools, 9 Adelaide L. Rev. 61 (1983); BS Chimni, Teaching, Research and Promotion of International Law in India: Past, Present and Future, 5 Sing. J. Int'l \& Comp. L. 368(2001); Hikmahanto Juwana, Teaching International Law in Indonesia, 5 Sing. J. Int'l \& Comp. L. 412 (2001); Isaak Dore, The International Law Program at Saint Louis University, 46 J. Legal Educ. 336 (1996); Diane Penneys Edelman, It Began at Brooklyn: Expanding Boundaries for First-Year Law Students by Internationalizing the Legal Writing Curriculum, 27 Brook. J. Int'l L. 415 (2002);

${ }^{5}$ See e.g., Michael Reisman, The Teaching of International Law in the Eighties, 20(3) the International Lawyer 987 (1986).

${ }^{6}$ See e.g. John C. Knechtle, Innovative Ways to Teach International Law, 97 Am. Soc'y Int'l L. Proc. 217 (2003); Diane Otto, Handmaidens, Hierarchies and Crossing the Public--Private Divide in the Teaching of International Law, 1 Melb. J. Int'l L. 35 (2000); John A. Barrett, International Legal Education in the United States: Being Educated for Domestic Practice While Living in a Global Society, 12 Am. U. J. Int'l L. \& Pol'y 975 (1997).
} 
law's peculiar identity inspired the older accounts, ${ }^{7}$ the changing face of legal education in light of market demands and challenges to those demands stir contemporary analyses.

Yet aside from variation of emphasis, the expanding literature has scarcely surpassed some of the insights of the older accounts in providing a meaningful outlook to international law pedagogy. The contemporary reactions continue to advance a largely selffulfilling iteration of constant discontent with the field's rank and recognition in legal education. It remains as true now as it was three decades ago, as one such reflective account put it then, that there is no state of emergency or grim exception disabling international law education and that the institutional knots and ties instead ought to be taken as an urging force for creativity and alternative thinking. ${ }^{8}$ In an equally compelling observation, Gerry Simpson warned against theoretical incoherence and depoliticization of the subject matter as a result of compromises that international law teachers often make in response to the perceived pedagogical, jurisprudential and functional inferiority of the field. ${ }^{9}$ These accounts are significant because their diagnoses and suggested remedies reject the sui generis status of international law and instead call for imaginative encounters with the possibilities that rules, doctrines, institutions and context offer to international legal education. They do so, however, by engaging with and challenging the assumptions of a peculiar and particularly undervalued disciplinary identity that prompt such extraordinary preoccupations in the first place.

But disciplinary existentialism may have well run its course. As this brief essay suggests, when reflecting on pedagogy in international law, we might do well to shift our gaze from the subject matter to the agent. An agent-based approach to the teaching of international law is not closed to existential considerations - the multiple personae of people with projects bear evidence to that after all. My interest here is nevertheless in a broader sense of agency than mere identity. As a preliminary attempt to entertain the interrelated frameworks of agency and virtue in international legal thinking, I take aid from virtue epistemology to point to a new approach to responsible and responsive pedagogy. The word 'virtue' might carry moral connotations and seem irrelevant to the acquisition of knowledge. In a broader sense, however, for virtue epistemologists virtue refers to human character traits, skills, and dispositions that normatively shape our cognitive connection to the world. ${ }^{10}$ As suggested here, a virtue-based account of knowing can provide an attractive normative framework to evaluate pedagogical choices.

Scholarly and pedagogical observational standpoints differ and can be defined to a reasonable degree, but to what extent and how may they justifiably delimit the teacher's discretion over methodological and substantive choices that she makes? Do we have a more reliable tool than the subjectivism of identity narratives to measure the success of our practice in an 'invisible college' of traveling minds who rise from the Global South and teach in the North and vice-versa? How to evaluate the pedagogical good (and possible harms) in unavoidably popular methodological approaches and styles such as interdisciplinarity and experientialism beyond their definite marketability? Might we sacrifice some crucial faculties in our pupils if we, for instance, allow our scholarly passion to overrule the practical wisdom of encouraging

\footnotetext{
${ }^{7}$ For an illustrative example, see especially Roundtable on the Teaching of International Law: Proceedings of the Eighty-Fifth Annual Meeting of the American Society of International Law, 85 Am. Soc'y Int'l L. Proc. 102 (1991).

${ }^{8}$ David Kennedy, International Legal Education, 26 Harv. Int'l L. J. 361, 384-5 (1985).

${ }^{9}$ Simpson, supra note 3.

${ }^{10}$ See e.g., Virtue Epistemology: Contemporary Readings, John Greco and John Turri, eds., (2012).
} 
dissent? But isn't dissent, too, subject to rules of epistemic responsibility? What, if anything, does responsible pedagogy have to do with coherence of our legal and political positions inside and outside of the classroom in between different scholarly and advocacy roles? And what about teaching from a critical standpoint as an overarching label?

Neither this essay nor virtue pedagogy has all the answers, but a virtue account offers new avenues for a more reflective stance on international law as an intellectual medium through which to relate to the world. Firstly, it directs the focus away from ontology to epistemology - although serious ontological (and methodological) questions are inevitably present - and thereby treats international legal studies as a mature endeavor deserving of difficult questions about knowledge that otherwise never see the light of day in a perpetual and tediously exaggerated state of disciplinary identity crisis. Secondly, it can afford an integrative approach to coherence in knowledge and ethics - in knowing and doing, in scholarship and teaching and so forth - without the baggage of moralizing foundations. Thirdly, precisely because of that integrative capability, a virtue-based approach can account for 'experience' - individual and otherwise - as a determinative factor in both pedagogical and scholarly choices without the danger of unrestrained subjectivity. Lastly, because it reconciles intellectual demands and dispositional traits, it makes no claim to having a hegemonic pedagogical blueprint and instead allows for responsible creativity.

With those promises, let us now turn to a brief outline of virtue epistemology before assessing its connection to a responsible, virtue-based approach to pedagogy.

\section{Virtue Epistemology}

Virtue theory, ${ }^{11}$ broadly speaking, centers on a number of important questions that are rooted in the Aristotelian virtue ethics tradition - the significance of agents as well as choice and action in moral theory, virtues, dispositions and character, moral discernment or wisdom, the role of emotions in our moral life, a deep concept of flourishing or happiness, and the fundamental questions of how one should live one's life and what sort of person to be. ${ }^{12}$ Virtue epistemology, in part influenced by the revival of interest in virtue ethics, gives epistemic or intellectual virtue concepts a central role in addressing questions of epistemic justification. ${ }^{13}$

\footnotetext{
${ }^{11}$ I deliberately avoided 'virtue theory' and used a more neutral phrase of 'virtue account' so far, because the former is taken to refer to considerations of virtue in dominant deontological and utilitarian moral traditions as well as to virtue ethics in particular. Having eclipsed in the $19^{\text {th }}$ century in favor of the two dominant moral traditions in Western philosophy, virtue ethics was revived in the late 1950s by G.E.M. Anscombe in Modern Moral Philosophy, 33 Philosophy (1958). This in turn led to development of various forms of virtue ethics inside and outside deontological and utilitarian approaches. Martha Nussbaum, in Virtue Ethics, A Misleading Category? 3 The Journal of Ethics 163 (1991) provides a lucid account of this complexity to reject a trichotomous taxonomy in which virtue ethics is regarded as a third, distinctive category against Kantians and utilitarians. Even though the relation between virtue epistemology and virtue ethics (an hence a clear account of the latter) is important, for the purposes of this essay, I am not concerned with clear designations and so use virtue theory or account in a broad sense to refer to a focus on virtue as reflected in the accompanying text.

${ }^{12}$ In Ancient Greek philosophy, these are excellence or virtue (arête), moral or practical wisdom (phronesis), and happiness or flourishing (eudaimonia). For a helpful account see Julia Annas, Intelligent Virtue (2011).

${ }^{13}$ The first application of virtue epistemology was in Ernest Sosa, The Raft and the Pyramid: Coherence versus Foundations in the Theory of Knowledge, V Midwest Studies in Philosophy 3 (1980).
} 
In defining the place of epistemology, philosophers are cognizant of its onceupon-a-time philosophical life when skepticism was a nemesis worthwhile to refute. It was the philosophical threat of skepticism that in principle warranted theorizing about knowledge. ${ }^{14}$ But, for modern epistemology, there are additional concerns or "problem-areas" that call for epistemological inquiry as a distinctive enterprise. One of those problem areas is the question of the value of knowledge, that is, if it should be of any importance for us to set knowledge as a goal, or the only goal, of inquiry, to answer the question of "knowledge for what?," and to know when and how we are justified to say 'we know.' Those who believe knowledge requires justification mostly adopt either a foundationalist or coherentist approach to the structure of justification. $^{15}$ Virtue epistemology, in contrast, shifts the focus from justification and evaluation of beliefs to that of the intellectual character of the agent, "so that knowers, or wouldbe knowers, come to bear as much of the onus of credibility as 'the known' has standardly borne." 16

A basic commitment of virtue epistemology, then, is to locate and evaluate epistemic credibility in intellectual agents and communities. The normative property of an act of cognition is measured against the cognitive character of the agent, and those cognitive characters are epistemic or intellectual virtues and vices.

A second and related tenet of virtue epistemology is that epistemology is in essence a normative discipline. ${ }^{17}$ For some epistemologists, that simply means the basic epistemic concepts of knowledge, justification and virtue can only be defined adequately in normative vocabulary, ${ }^{18}$ while for others it implies an educational or practical mission for epistemology to nurture our intellectual well-being by, amongst others, helping us to recognize modes of "epistemic injustice" 19 or furnishing us with forms of intellectual virtue to inspire intellectual flourishing or cultural reformation. ${ }^{20}$

What exactly constitutes intellectual virtues turns on whether they are regarded by epistemologists merely as a critical means conducive to intellectual flourishing or as both a critical means to intellectual well-being and partly constitutive of that. Cognitive faculties such as memory, perception, and introspection, for instance, as reliable and stable means of getting to the truth, define intellectual virtues for epistemologists who are concerned with virtue-based analysis of knowledge. But for those who are concerned with cognition's ethical implications and epistemic responsibility, refined intellectual character traits such as open-mindedness, fair-

\footnotetext{
${ }^{14}$ See generally Alfred Jules Ayer, The Problem of KNOWLedge (1956).

${ }^{15}$ The problem of justification is as follows: every belief $C$ must be inferentially justified by a belief $\mathrm{E}$, which in turn needs to be justified by another belief $\mathrm{F}$, which needs to be justified by yet another belief G, ad infinitum. Foundationalism would have the regress end with some empirically basic or non-inferentially justified beliefs in no need of further justification. The coherentist, on the other hand, considers justification to be inferential in a circular or weblike, rather than linear, manner. See e.g., Michael Williams, Problems of Knowledge: A Critical Introduction to Epistemology, 81-90, and 117-23 (2001).

${ }^{16}$ Lorraine Code, Epistemic Responsibility, 8-9 (1987).

${ }^{17}$ This is in opposition to Willard Van Orman Quine's suggestion, in Epistemology Naturalized in ONTOLOGICAL RELATIVITY AND OTHER ESSAYS, 80 (1969), that the questions of justification and what to believe should give place to cognitive psychology.

${ }^{18}$ See e.g. Linda Zagzebski, On Epistemology (2009).

${ }^{19}$ Miranda Fricker, Epistemic Injustice: Power and the Ethics of Knowing (2007).

${ }^{20}$ Robert C. Roberts and W. Jay Wood, Intellectual Virtues: An Essay in Regulative Epistemology (2007).
} 
mindedness, tenacity, thoroughness, and conscientiousness, rather than cognitive faculties, make up intellectual virtues. ${ }^{21}$

This is not, and ought not to be, a sharp taxonomy. A complete epistemology plausibly requires both faculty and character trait virtues. The former are indispensible to giving us access to existing knowledge and the world around us, and the latter to facilitating richer intellectual achievements such as wisdom and understanding that may go beyond mere knowledge. $^{22}$ It is nonetheless epistemologists' attention to intellectual character traits that suggests some exciting and non-traditional epistemic possibilities.

One such attempt broadens the scope of epistemology by urging a focus on personal and social aspects of cognitive life and by considering epistemic responsibility as chief among intellectual virtues. ${ }^{23}$ Under another account, the chief intellectual virtue is epistemic conscientiousness, which is a desire to reach truth and avoid error. ${ }^{24}$ Additional intellectual virtues such as impartiality (including openness to opposing ideas and a lively sense of one's own fallibility), intellectual sobriety (as opposed to the enthusiast who is likely to embrace what is not really warranted), and courage (including willingness to explore alternatives to popular beliefs, perseverance against opposition until one is convinced that one is mistaken, and determination to see such new inquiry through the end) are required to regulate a desire for truth since that desire is not a virtue on its face and could be compatible with vices of fanaticism and dogmatism. $^{25}$ Concerned with the social aspects of knowledge, a third account points to virtue epistemology's disregard of a distinction, long made in virtue ethics, between self-regarding and other-regarding virtues. Perceptual acuity and intellectual courage promote the individual's own intellectual flourishing, while the agent's honesty and integrity promote others' intellectual flourishing by enabling her to clearly communicate her reasons to others or demonstrate creativity to discover knowledge new to a community. ${ }^{26}$

Along the lines of social and historical concerns, some have argued for a genetic or social approach to epistemology, which instead of focusing on knowledge at a particular point in time, considers the cognitive life of the mind developed in a social context. Under this account, virtues help shed light on the cognitive life of the mind and its socialization as they also play a central role in defining cognitive ideals in context. ${ }^{27}$ A thorough grasp of the development of cognitive ideals requires attention to concepts such as "social patterns of mimicry and imitation" and "the importance of training and practice in learning how to search for the truth." 28 It also accounts "for the superiority from an epistemological point of view of certain communities and the bodies of knowledge they generate," and hence for considering why physics and scientific educational material, for instance, are more respectable than astrology. ${ }^{29}$

\footnotetext{
${ }^{21}$ These two views are known as ‘virtue reliabilism' and ‘virtue responsibilism' respectively.

${ }^{22}$ Linda Zagzebski, Recovering Understanding, in Knowledge Truth, and Duty: Essays on Epistemic Justification, Responsibility, and Virtue, Matthias Steup ed., 248-49 (2001). Se also Jason Baehr, Character, Reliability and Virtue Epistemology, 56 The Philosophical Quarterly 193 (2006).

${ }^{23}$ Code, supra note 16 at 44.

${ }^{24}$ James Monmarquet, Epistemic Virtue and Doxastic Responsibility, 21 (1993).

${ }^{25}$ Ibid. at 23.

${ }^{26}$ Jason Kawall, Other-Regarding Epistemic Virtues, 15(3) Ratio 257, 260 (2002).

27 Jonathon Kvanvig, The Intellectual Virtues and the Life of the Mind (1992).

${ }^{28}$ Ibid. at 172 .

${ }^{29}$ Ibid. at 176 .
} 
Finally, a Neo-Aristotelian account of virtue epistemology holds an integrative view of moral and epistemic virtues and argues that just as in Aristotelian moral virtues where both 'motivational' and 'reliable success' components are present, intellectual virtues also motivationally and reliably define justification. An individual exhibiting intellectual courage, for instance, is motivated to persevere in her ideas out of a desire for truth and is reliably successful at doing so. ${ }^{30}$ Just as in moral virtues, intellectual virtues may conflict - intellectual courage and humility, or generosity and autonomy may pull in different directions. In such cases, the agent relies on Aristotelian phronesis or the virtue of practical wisdom to balance the conflicting demands of a given situation and respond appropriately. ${ }^{31}$

This is a sketch without a critical assessment of the contribution and shortcomings of various positions in virtue epistemology. It nonetheless suffices to demonstrate the significance of a normative approach to epistemology. The addition of intellectual character traits to cognitive faculties further moves our grasp of the world from mere perception and knowledge to understanding, wisdom and intellectual flourishing. Virtue epistemologists interested in the social and ethical aspects of knowledge present intellectual courage, humility, practical wisdom, love of knowledge, generosity and autonomy, in philosophical depth, to outline the ways these virtues ought to guide our cognitive connection to the world, ${ }^{32}$ and the ways virtues and vices such as epistemic sensibility, temperance, or self-indulgence can promote or hinder intellectual flourishing. ${ }^{33}$ Notably, the virtue of epistemic justice requires "reflexive critical openness" to the voices of the less powerful and marginalized who are often dismissed due to various forms of cognitive and social prejudice. ${ }^{34}$ Originally discussed in the context of the politics of testimony, ${ }^{35}$ epistemic justice urges further reflection on questions of power and credibility on a considerably larger level of social and political inquiry. reflexive pedagogy?

But how can responsibilism in virtue epistemology guide responsible and

\section{Virtue Pedagogy and Pedagogical Persona}

Teaching can be understood in three distinct but interrelated senses: as a practice, a role, or an activity. ${ }^{36}$ It seems to me that institutional and individual practices and roles adopted in order to realize the ends of teaching, normative as they might be, follow from an understanding of teaching as an activity. I use the notion of a "pedagogical persona" to refer to the overall character which the agent adopts while conducting the activity of teaching rather than to various roles or practices she may follow to achieve defined ends through that persona. This is partly inspired by what, in close similarity to scientific personae, Herman Paul calls 'scholarly

\footnotetext{
${ }^{30}$ For the most developed account, see Linda Zagzebski, Virtues of the Mind: An Inquiry into the Nature of Virtue and the Ethical Foundations of Knowledge (1996).

${ }^{31}$ Roberts and Wood, supra note 20 at 311.

${ }^{32}$ See ibid. at 165, 206, 219, 250, 261, 293, and 311.

33 See Heather Battaly, Epistemic Self-Indulgence, 41 Metaphilosophy 214 (2010).

${ }^{34}$ Miranda Fricker, Epistemic Injustice and a Role for Virtue in the Politics of Knowing, 34 Metaphilosophy 154, 154.

${ }^{35}$ See ibid. 154-61.

${ }^{36}$ David Carr, Making Sense of Education, 19 (2003).
} 
persona' in the philosophy of history, ${ }^{37}$ an ideal-typical model that allows for consideration of a constellation of features with which an activity is pursued rather than a single-focused embodiment of one episodic instance of scholarly engagement. Paul introduces "scholarly personae as models of scholarly selfhood, or as models of abilities, attitudes, and dispositions that are considered to be crucial for the pursuit of scholarly study." ${ }^{38}$ He draws out the implications of persona as a collection of virtues and skills to offer a more holistic understanding of what it means to be a historian, though nothing in his account limits the concept to scholarship or history as such. For Paul, skills are the technical proficiency or mastery required to accomplish the tasks of a particular practice, ${ }^{39}$ but virtues are something more: "they are oriented toward goods that their practitioners recognize as constitutive of the practices (for example, moral inquiry, scholarly research, political deliberation) in which they find themselves engaged. ${ }^{40}$

As Paul admits, this conception of virtue has a constructivist element beyond its Aristotelian roots, which regard goods that define virtue as given and not subject to the individual's discretion. Under Paul's model, virtues are not frozen in time, but are necessary to pursue the goods regarded as constitutive of a particular activity by its practitioners in a particular time. ${ }^{41}$ In agreement with Paul, I am not interested in a 'moral' ${ }^{42}$ or 'personal worth' ${ }^{43}$ conception of virtue. However, I part ways with Paul's constructivist understanding of virtue which is meant to give persona a temporal or contextual character. Instead, I take persona to stand for the kind of selfhood that the agent, based on her understanding of the activity in question, defines for herself. Virtues are human qualities and traits that normatively direct, rather than descriptively explain, the agent's choice of persona and the particular ways she acts in that persona to achieve the desired ends of her activity with reliable success.

More specifically, I use pedagogical personae to point to the kind of selves that agents, based on their understanding of the art or science of teaching as an activity, adopt and exhibit while they perform and engage in multiple roles and practices to achieve the ends of education. Epistemic virtues, given the nature of the activity, seem to be the best candidates to guide the agent in her choice of the persona and resulting roles and practices. Such rolls and practices may range from course designing, classroom teaching, research and independent study supervision, evaluation and any other operation that is ordinarily part of teaching activities. Pedagogy, taken broadly, implies an understanding of what is appropriate and what is inappropriate knowledge (again in a broad sense of those qualifiers) to impart through education and includes an "animating ethos" in a pedagogue. ${ }^{44}$

\footnotetext{
${ }^{37}$ Herman Paul, What is a Scholarly Persona? Ten Theses on Virtues, Skills and Desires, 53(3) History and Theory 348 (2014).

${ }^{38}$ Ibid. 353.

${ }^{39}$ Ibid. 358.

${ }^{40}$ Ibid. 359.

${ }^{41}$ Ibid.

${ }^{42}$ See Zagzebski, Virtues of the Mind, supra note 30 at 108. I do not necessarily reject that a virtuous person is more likely to be a moral person than a nonvirtuous person, but as stated before, here I need not take any position on the relationship between virtue epistemology and virtue ethics.

${ }^{43}$ Jason Baehr, The Inquiring Mind: On Intellectual Virtues and Virtue Epistemology, 88-111 (2012) cited in Paul, supra note 41 at 359.

${ }^{44}$ Max van Manen, Pedagogy, Virtue, and Narrative Identity in Teaching, 24(2) Curriculum Inquiry 135, 139 (1994).
} 
A case for virtue epistemology as an attractive normative account for assessing responsible pedagogy stands on solid legs of cognitive faculties and intellectual character traits in justification of pedagogical choices of all kinds. The application of virtue theory to pedagogy, in particular when promoted through advocacy for the use of identity narrative and other noncognitive means to cultivate wisdom and understanding beyond the mere transfer of knowledge, ${ }^{45}$ has raised skepticism about the capacity of non-cognitive tools to avoid falsehood and deception and mistaking the particular for the universal. ${ }^{46}$ In response to that challenge, an advocate of virtue pedagogy argues that "there are forms of understanding that transcend the conceptual" and uses virtues such as "pedagogical tact," "personal presence," "discipline," and "patience" to respond to both "conceptual and cognitive" and "evocative and noncognitive" dimensions in human science inquiry. ${ }^{47}$ This is hardly a response, as 'understanding' in human science inquiry need not be noncognitive. Besides, the virtues invoked are also too general and too blunt to contribute much by way of effective and sharp checks and balances against the folly of pure subjectivism.

Here is precisely where virtue epistemology, as compared to other forms of virtue theory, remains unparalleled for the value of its emphasis on demanding norms of cognitive justification in line with desired normative social or ethical implications. As alluded to earlier, the dividing line between virtue epistemologists focusing on reliable cognitive faculties and the responsibilists is one of difference of emphasis rather than a choice between cognitive and noncognitive features or stronger and weaker cognitive capacity. Cognitive and character related intellectual virtues together accommodate historical and social situatedness of knowledge without sacrificing measures of reliability. Qualities such as open-mindedness, integrity, conscientiousness, tenacity, thoroughness and so on may seem too abstract and global to direct the pedagogical agent in a meaningful way to pursue her activity that is both reliable and context-sensitive. But it is in fact the virtue of practical wisdom that enables the agent to interpret the demands of intellectual character traits on the inquiry and balance between such demands in case of arising conflicts.

Once the agent defines her pedagogical persona according to her understanding of the activity - what teaching is all about and what kinds of goods it pursues as the ends justifying the activity toward the ultimate end of intellectual well-being - virtues as normative qualities act both as a critical means to and partly constitutive of intellectual well-being to guide various roles and practices embedded in the activity. Global as epistemic virtues might be, their interpretation and application in context as normative guides under the light of practical wisdom is the agent's responsibility. There is no reason to hold intellectual character virtues exempt from critical reflection. But the broad agency of the individual in interpretation and balancing of the normative demands of these virtues will leave ample room for context-sensitivity.

Different skills and abilities distinguish teachers in what kind of technical tasks they can tackle, but different intellectual dispositions and attitudes distinguish between more or less normatively justified pedagogical choices. The implications of virtues for international law teaching are no less salient than an agent-based approach to pedagogy deserves. To make sense

\footnotetext{
${ }^{45}$ For a prime example, see ibid.

${ }^{46}$ Gary D. Fenstermacher, On the Virtues of van Manen's Argument: A Response to "Pedagogy, Virtue, and Narrative Identity in Teaching," 24(2) Curriculum Inquiry 215 (1994).

${ }^{47}$ Max van Manen, The Pain of Science: Rejoining Fenstermacher's Response, 24(2) Curriculum Inquiry 221, 22627 (1994).
} 
of the normative relevance and significance of virtues, defined as such, for international law teaching, let us consider a few instances of pedagogical problem-areas that manifest the operation of virtue theory for the inquiring agent. The coverage is admittedly eclectic and the exercise intended to draw attention to the resulting inquiry and questions to be asked under a virtue account rather than to provide a blueprint. Befitting the normative approach it advocates, in a way it speaks of the author's dispositions and attitudes, and so with luck, the invoked virtues ought to point to the right questions and guard against intellectual self-indulgence as well.

\section{Virtue Pedagogy and International Law Teaching}

Contra international law teaching, international legal scholarship has invited some serious reflections on the role of scholars as agents in their connection to the world through scholarly intervention. Normative views of the role or responsibilities of international legal scholars posit a collective as a community. Whether this collective is an epistemic community built on common forms of access to and production of knowledge, an interpretive community reflecting common forms of reading legal texts, or simply a professional community, divergence of ideas about the justificatory goals of its scholarly production is sharp enough to extend along different theories about law.

On one extreme of some illustrative recent accounts, a detached scholarly position must contain 'second-order legal scholarship' to the analysis of the origin and doctrinal structure of norms, their influence on perceptions and preferences, and their interaction with one another a tempered exercise of the far more extreme Kelsenian 'reflexive distance' position. ${ }^{48}$ Reconciling positivism and politics, 'critical positivism' takes rules seriously as it urges full sensitivity to the socio-economic and ideological context of their creation. ${ }^{49}$ Inspired by virtue ethics, a creative reading of Martti Koskenniemi's 'culture of formalism' understands it to be a recognition of the demands of individual ethical responsibility on, among others, international law scholars. ${ }^{50}$ Another stance perhaps at the other extreme end of current outlooks on positioning international law scholars, and in my view also closely related to virtue ethics, is one that understands professional (and individual) 'sensibilities' as “disciplinary habits of thought, assumptions, and dispositions" that invite international law scholars to a more reflective consideration of their individual and collective ethical responsibilities. ${ }^{51}$ This last account adds another crucial element to 'sensibility' for effective agency, which is a proper cognitive infrastructure to organize responsible engagement with the world. ${ }^{52}$

To fill the lacuna of an agent-based approach to international law teaching, epistemic virtues help guide this recognition - sensibility - in a responsible manner. If, as suggested before, epistemic virtues are the best normative candidates to guide the agent in her

48 Jochen von Bernstorff, International Legal Scholarship as a Cooling Medium in International Law and Politics, 25(4) Eur. J. Int'l L. 977, 990 (2014). For a simpler account wary of accountability of scholars to the 'scientific community', 'the truth', and 'the public', see Anne Peters, Realizing Utopia as a Scholarly Endeavour, 24(2) Eur. J. Int'l L. 533, 540 (2013).

${ }^{49}$ Realizing Utopia: the Future of International Law, Antonio Cassese ed., xvii (2012).

50 Jan Klabbers, Towards a Culture of Formalism? Martti Koskenniemi and the Virtues, 27 Temp. Int'l \& Comp. L. J. 417, 420-21 (2013).

${ }^{51}$ Andrew Lang and Susan Marks, People with Projects: Writing the Lives of International Lawyers, 27 Temp. Int'l \& Comp. L. J. 437, 449 (2013).

52 Ibid. 452. 
choice of pedagogical persona and resulting roles and practices, it is because they include habits, dispositions, skills, and attitudes under both cognitive faculties and intellectual character traits. Virtue pedagogy, then, takes account of dispositions, attitudes and habits in the pedagogical agent as it also insists on a cognitive infrastructure that is epistemically both reliable and responsible.

Take, for instance, critical approaches to international law teaching. Decades on, the critique against reproduction of hierarchy through legal education ${ }^{53}$ and the later call for politicization of the classroom ${ }^{54}$ still undeniably reverberate through understandings of critical pedagogy in (international) law. At their core, such efforts cut through various forms of contingency of knowledge while their emancipatory ideals aspire to expose the role of hegemony and power in its formation. It would be reductive to seek one uniform definition and associated methods for critical pedagogy in general. ${ }^{55}$ Grounded in the critiques of the Frankfurt School and especially Herbert Marcuse against the role of schools in solidifying authority and undermining the necessary social consciousness for social change, ${ }^{56}$ various concerns have preoccupied critical pedagogy theories in the past few decades. These aspirations unite in urging anti-oppressive praxis ${ }^{57}$ centering on race, gender, nationality, ethnicity, sexuality, and so on. In their post-modern incarnation, they go so far as to advocate a global decolonizing role for education by, for instance, reviving indigenous knowledge. ${ }^{58}$

Critical legal pedagogy, in turn, shares similar ideals. At times, explicitly relying on a Gramscian anti-hegemonic framework, it envisions decolonizing the self and society through 'identity politics as anti-subordination praxis' ${ }^{59}$ Critical international law pedagogy, too, has fed on strands of identity politics, with Third World Approaches to International Law (TWAIL) perhaps having inspired the most inclusive manifestation of critical ideals of education in international law. ${ }^{60}$ TWAIL's theoretical commitment to emancipation, equality, positional parity, agency for change, empowerment, anti-subordination, historicity, contextualism, antidualism, inclusion, and expansion of the political informs a pedagogical approach that contains, but goes well beyond, mere identity politics. ${ }^{61}$ The subversive nature of such reorientation aims to do more than merely challenge banking models of education, in which the teacher deposits information into passive deposit boxes as pupils, and which are the main target of critical pedagogy theories. $^{62}$ It does not remain content, then, with a reproduction of a hierarchical relationship where the pedagogue only transfers TWAIL teachings as a transaction. Instead, it places the pedagogue in a non-hierarchical, dialogical relationship with the pupil to explore

\footnotetext{
${ }^{53}$ D Kennedy, Legal Education and the Reproduction of Hierarchy, 32 J. Leg. Educ. 591 (1982).

${ }^{54}$ Duncan Kennedy, Politicizing the Classroom, 4 S. Cal. Rev. L. \& Women's Stud 81 (1994).

${ }^{55}$ For a qualitative study of different understandings of the concept among self-identified pedagogues, see Mary Breuing, Problematizing Critical Pedagogy 3(3) Int'l J. Crit. Pedagogy 2 (2011).

${ }^{56}$ See e.g. Michael Apple, Education and Power (1982).

${ }^{57}$ Paulo Freire's Pedagogy of the Oppressed (1970) is often regarded as the first theoretical articulation of critical pedagogy.

${ }^{58}$ See in particular, Sandy Grande, Red Pedagogy: Native American Social and Political Thought (2004).

${ }^{59}$ See e.g., Francisco Valdes, Outsider Jurisprudence, Critical Pedagogy and Social Justice Activism: Marking the Stirrings of Critical Legal Education, 10 Asian A. L. J. 65 (2003).

${ }^{60}$ Mohsen al-Attar \& Vernon Tava, TWAIL Pedagogy: Legal Education for Emancipation, XV PalestineY. Of Int'l L. 7 (2009).

${ }^{61}$ See ibid. for one attempt at detailing an actual experience with designing a course on this basis.

${ }^{62}$ Freire, supra note 57 at 53. For a superb example of dissent against the banking model in international law teaching, see Otto, supra note 6.
} 
together alternative theoretical sources for knowledge through the context of often-ignored sites and voices for emancipatory praxes.

If this summary is accurate, I propose that all the axes of critical international law pedagogy, understood as such, would normatively benefit from an agent-based approach governed by epistemic virtues.

To start with the non-hierarchical and dialogical nature of the pedagogue-pupil relationship, it ought to be asked what exactly symmetry - invoked to question traditional sources of authority including those of the pedagogue - means in this context. ${ }^{63}$ If symmetry refers to the space given to the pupil to reason and analyze the material independently, that in and of itself may not carry much distinctive analytical weight as a characteristic of this relationship to argue for it in a theory of education. ${ }^{64}$ But if symmetry refers to epistemic or pedagogical parity between the pedagogue and pupil, then it is dubious how that could ensure the realization of telos of critical teaching - training with appropriate cognitive tools for effective agency for change and emancipation.

The fact that dialogical exploration of sources of domination, old and new, guards against a robotic reproduction of the teacher's preoccupations gives it legitimacy. But the pedagogue, by virtue of practice, is more likely to have cultivated intellectual character traits such as open-mindedness and generosity and be able to exercise appropriate cognitive tools to interpret, identify, and debunk traditional sources of knowledge that reinforce or neutralize various ploys of domination. Destruction of the canon needs no less epistemic responsibility than multiplication of new, more inclusive sources of knowledge. Positivism and formalism, as often the easiest targets of critical international law pedagogy, ${ }^{65}$ are weighty adversaries worthy of necessary cognitive and virtuous intellectual character traits already developed in the pedagogue to be imparted in the process of critical education.

The search for alternative theoretical sources of knowledge also needs epistemic justification. Theoretical inclinations, particularly outside the natural world, to a large extent reflect dispositions or temperaments. Empiricism or abstract thinking, social and ethical implications attributed to different theoretical orientations, and distinctive methodological demands associated with different theoretical perspectives appeal to scholars partly based on diverging temperaments. Yet, although sensibilities partly explain theoretical choices, they do not justify them. Theories need cognitive rather than metacognitive justification.

To teach dissent from dominant theoretical approaches in favor of new explanatory or normative theories requires, first and foremost, full engagement with those approaches on their own terms. Whether through 'narrowing of the focus followed by a broadening of perspective" ${ }^{\text {,66 }}$ in which several theoretical frameworks are brought to bear on a particular problem-area, a phenomenological approach which finds a case to be worth

\footnotetext{
${ }^{63}$ I borrow Martha Nussbaum's reference to 'pedagogical symmetry' to refer to the rejection of a hierarchical relationship here, without engaging with her particular elaboration on the subject. See The Therapy of Desire, 340 infra (2009).

${ }^{64}$ For an essentially similar, but more complex, critique of Nussbaum's articulation of pedagogical symmetry, see David Moltow, Pedagogical Symmetry and the Cultivation of Humanity: Nussbaum, Seneca and Symmetry in the Teacher-Pupil Relationship, 13(1-2) Arts and Humanities in Higher Education 115, 117 (2014).

${ }^{65}$ See e.g., al-Attar \& Tava, supra note 60 at 23.

${ }^{66}$ Simpson, supra note 3 at 89.
} 
anatomizing "when it both typifies and enacts fundamental legal controversies of the sort that go on in a variety of distinct substantive settings," 67 or a purely abstract comparative study of theoretical orientations towards the global legal order, critical pedagogy must teach how to push the object of critique to its limit, on its own terms, to expose its ills. Rational choice approaches, for instance, can hardly withstand the philosophical scrutiny of 'self' and 'rationality' if the pedagogue takes their claims seriously to develop a critique from within rather than without. Sociological claims of human rights norm internalization may well fall short if assessed against valid empirical observations. Likewise, procedural accounts of legitimacy betray a tall order of assumptions of substantive justice for a pluralistic global community. But that will become obvious only if they are taken seriously on their detailed claims rather than dismissed offhand. ${ }^{68}$

In short, the association of theories with political or ethical orientations and methodological choices must be proved rather than assumed. Critical pedagogy's legitimacy owes to how it takes this as both a responsibility and an opportunity. Shortcut descriptors such as anti-subordination and universalism cannot do the filtering job alone. Theories feeding critical international legal pedagogy are susceptible to unwarranted universalism as well. Our understanding of social phenomena - revolutions, urbanization, immigration, social movements and so on - could draw from large-scale, grand critical social and political theories of the nineteenth and twentieth centuries too in such a way as to lose touch with particularities of various locales to which our limited cognitive tools may not afford access. Epistemic virtues urge the critical pedagogue to take her dispositions seriously, treat them reflexively, and acquire habits that are in line with intellectual virtues of humility, courage, open-mindedness and impartiality, autonomy, and conscientiousness in order to teach how to responsibly question the canon and develop new theories against subordination and colonization of the self and society.

Most notably, critical international law pedagogy's reliance on alternative sites and marginalized voices for more inclusive sources of knowledge and emancipatory praxis responds to demands of epistemic justice. These narratives are retrievable on the streets of the metropole as much as in "relatable hinterlands." 69 Notwithstanding what form suppression and convenient collective amnesia have historically taken, these sites and voices have continued to share a second-class fate, and with that the welfare of millions.

Again, dispositions by and large determine which voices call out to us more audibly and to what extent we take them to represent indefensible oppressive practices. Yet we need reliable discriminating capacity to select and treat such alternative narratives as media for new knowledge. Any objection against such selectivity could preemptively be addressed by the fact that our cognitive tools and emotive resources are inevitably limited, and so we constantly select those narratives that we can access and identify with over those we cannot and do not. Epistemic virtues enable the agent to discriminate consciously and legitimately and guard against both arbitrariness and subjectivism. A commitment to self-criticality in the pedagogue would ensure both intellectual reliability and responsibility in the selection, presentation and interpretation of narratives whose reach goes beyond the idiosyncrasies of personal identity. Self-criticality, however, is not non-cognitive. Rather, it calls for both appropriate cognitive

\footnotetext{
${ }^{67}$ Richard Falk, New Approaches to the Study of International Law, Am. J. Int'l L. 477, 495 (1967).

${ }^{68}$ For a case of such hasty dismissal, see al-Attar \& Tava, supra note 60 at 22.

69 The phrase is borrowed from Robbie Shilliam, Colonial Architecture or Related Hinterlands? Locke, Nandy, Fanon, and the Bandung Spirit, 22(2) Constellations (2015).
} 
faculties to reliably relate to the existing knowledge and intellectual character traits to responsibly open the space for new sources.

By shifting the focus from the disciplinary or institutional identity of the field to the agency of the pedagogue, virtue pedagogy poses demanding epistemic requirements on teaching international law as a vocation that fosters intellectual well-being both as an end in itself and as a means to more democratic processes of constructing emancipatory knowledge. The 1990s divide between critical and mainstream international law teaching crucially raised consciousness toward institutional recognition of critical teaching as a heresy. But those defined boundaries are now behind us. Critical orientations in international law - even the factions specifically inspired by TWAIL - proceed with very different moral and political priorities and, at times, converge around only a faith in emancipatory praxes. What is conveniently termed mainstream also carries various interdisciplinary flags and acts on diverging interests. So the old framing does not seem to be as analytically sharp as it may once have been, nor is it proving strategically productive. Moreover, the vast waves of information vying for students' attention seems to deflate concerns about banking models of education in a law school course on international law. Rather than relying on classic dichotomies and longstanding critiques of education as hierarchy, we ought to focus our individual and collective efforts on fostering critical international law pedagogy as an epistemically robust and responsible intellectual enterprise.

This is ever more urgent considering that a network of critical approaches is increasingly in a dialogue and that mobility, digital and otherwise, is the new career reality. How would we teach international law critically to a classroom in a country whose plight of various kinds has animated our critical theories but which has no share of its own in critical scholarly literature? The majority of theoretical sources guiding critical international law approaches still come in English. We can overcome linguistic barriers more easily, but lexicon barriers require patience and strong intellectual tools to maneuver. What should we make, for example, of the reception of critical work examining the adverse consequences of feminist interventions in international human rights and humanitarian law's treatment of women in peace and war by a class of female lawyers in a country where years of their life were limited to seclusion and professional retardation by an oppressive regime that confined them to darkness? How to convince young, aspiring lawyers about the costs associated with using the language of international human rights in a context where defense of civil and political rights still defines life and death? The question is not over strategies, as survival tactics have often taught these students enough wickedly pragmatic wisdom to find their way around. It is rather a question about the future of critical pedagogy not just in what it teaches but also in what it learns. It is about urging agency in pedagogues to acquire skills, habits and dispositions to transcend homey personal identities, if and when needed, and exercise self-criticality in an epistemically responsible way. It is also about adopting sufficient artistic expression and practical wisdom, from humanities or other cognitive fields, not to have to present the complicated truth as a lie or as a subjective choice of a narrative. 